\title{
EFFECT OF SODIUM IODIDE, MAGNESIUM SULFATE, THYROXIN, AND THYROTROPIC HORMONE ON THE BLOOD MAGNESIUM PARTITION ${ }^{1}$
}

\author{
BY LOUIS J. SOFFER, CLARENCE COHN,2 GERSON LESNICK,? \\ HARRY SOBOTKA, AND MILDRED JACOBS \\ (From the Medical Service of Dr. George Baehr, and the Department of Chemistry of the Laboratories \\ of The Mount Sinai Hospital, New York City)
}

(Received for publication September 30, 1943)

In previous papers $(1,2)$, we reported the fact that, in patients with Graves' disease, there occurred a considerable increase in the percentage of bound magnesium found in the circulating blood. In normal individuals, the percentage of bound magnesium varied between 10 and 20 per cent, while in patients with Graves' disease, the percentage of bound magnesium was usually in excess of 25 per cent, and attained as high a level as 60 per cent. In patients with myxedema, the reverse was true, and in these cases, all or almost all the circulating blood magnesium was in the ionized form. Following Lugolization of the patients with hyperthyroidism, there occurred a fall in the percentage of bound magnesium, and following operation (sub-total thyroidectomy), this figure fell further to normal or even sub-normal levels. These results were subsequently confirmed by Dine and Lavietes (3), whereas Cope and Wolff (4) failed to corroborate them.

The object of this report is to present the results obtained in the investigation of certain factors which might conceivably influence the blood magnesium partition.

\section{METHODS}

Normal dogs were employed for the present investigation. Blood magnesium partition studies were carried out following the intravenous administration of sodium iodide and magnesium sulfate, and the subcutaneous injection of thyroxin and thyrotropic hormone.

The total serum magnesium was determined by the method of Briggs (5). The serum proteins were precipitated with trichloroacetic acid. It was found that little, if any, magnesium was carried down with the protein

\footnotetext{
1 Aided by a Grant from the Ciba Pharmaceutical Company, Summit, New Jersey.

2 Captain, U. S. A. M. C.; Eugene Meyer, Jr., Fellow.

First lieutenant, U. S. A. M. C.; Charles Klingenstein Fellow.
}

flocculum. To $10 \mathrm{cc}$. of protein-free filtrate were added 1 cc. of 20 per cent sodium acetate, 6 to 8 drops of 0.016 per cent bromcresol green, and 1 cc. of 4 per cent ammonium oxalate. The $\mathrm{pH}$ of the solution was adjusted to $\mathbf{5 . 0}$ by addition of ammonium hydroxide. The mixture was allowed to stand overnight, and the precipitated calcium oxalate then separated by centrifugation. To the decanted supernatant fluid and washings were added $1 \mathrm{cc}$. of 2 per cent potassium dihydrogen phosphate and $1 \mathrm{cc}$. of concentrated ammonia solution. After the mixture had again been allowed to stand overnight, the precipitate was separated by centrifugation and washed with a solution containing $200 \mathrm{cc}$. of 95 per cent alcohol and $50 \mathrm{cc}$. of concentrated ammonia solution per liter. The precipitated magnesium ammonium phosphate was dried and determined according to the method of Kuttner and Lichtenstein (6) by comparison of the color developed on addition of 7.5 per cent sodium molybdate and 0.2 per cent stannous chloride with that of a standard phosphate stock solution.

For the determination of diffusible magnesium, serum was ultrafiltered with the apparatus of Dine and Lavietes. The magnesium content of the ultrafiltrate was determined as described above, except that the protein precipitation with trichloroacetic acid was omitted.

\section{RESULTS}

Sodium iodide. Two dogs, numbers 313 and 420 , were given 0.5 gram of sodium iodide intravenously, daily. Dog number 313 was thus treated for 31 days. The drug was then discontinued and further observations were conducted for an additional 35-day period. Total blood magnesium and magnesium partition studies were conducted at intervals of approximately 1 to 2 weeks. It will be seen from Table I that in this instance, there was practically no change in either the total or the percentage of bound magnesium. Essentially the same was true for dog number 420 , similarly treated. It is interesting to note that in patients with Graves' disease, the administration of iodine results in a prompt reduction in the percentage of bound magnesium. In the normal dog, however, no such change occurs. Preliminary experiments 
TABLE I

Effect of sodium iodide on total blood magnesium and percentage of bound magnesium

\begin{tabular}{c|c|c|c|c|c|c|c}
\hline \hline $\begin{array}{c}\text { Dog } \\
\text { num- } \\
\text { ber }\end{array}$ & Days & $\begin{array}{c}\text { Total } \\
\text { blood } \\
\mathbf{M g}\end{array}$ & $\begin{array}{c}\text { Bound } \\
\mathbf{M g}\end{array}$ & $\begin{array}{c}\text { Dog } \\
\text { num- } \\
\text { ber }\end{array}$ & Days & $\begin{array}{c}\text { Total } \\
\text { blood } \\
\mathbf{M g}\end{array}$ & $\begin{array}{c}\text { Bound } \\
\mathbf{M g}\end{array}$ \\
\hline $\begin{array}{c}\text { mgm. } \\
\text { per cent } \\
\text { (Con- } \\
\text { trol) }\end{array}$ & $\begin{array}{c}\text { per cent } \\
2.69\end{array}$ & 21.2 & 420 & $\begin{array}{c}0 \\
\text { (Con- } \\
\text { trol) }\end{array}$ & $\begin{array}{c}\text { mgm. } \\
\text { per cent } \\
2.64\end{array}$ & $\begin{array}{c}\text { per cent } \\
25.3\end{array}$ \\
\hline
\end{tabular}

5 cc. 10 per cent Sodium Iodide Intravenously Daily

\begin{tabular}{c|l|l|l|l|l|l|l}
\hline & 12 & 2.77 & 27.8 & & 11 & 1.94 & 20.1 \\
31 & 2.73 & 25.6 & & 21 & 2.16 & 29.6 \\
\hline & Injections Discontinued \\
\hline & 55 & 2.73 & 25.6 & 33 & 2.18 & 25.2 \\
\hline 66 & 2.80 & 23.5 & 55 & 2.61 & 26.0 \\
\hline
\end{tabular}

with normal humans who have been given Lugol's solution yield results similar to those obtained in normal dogs.

Magnesium sulfate. Two dogs, numbers 313 and 411 , were given $3 \mathrm{cc}$. of a 25 per cent solution of magnesium sulfate intravenously, daily, for $\mathbf{4 2}$ days and for 75 days, respectively (Table II). The drug was then discontinued but continuing observations were carried on for an additional period of 67 days. In neither animal did the magnesium sulfate exercise an appreciable effect on the total serum magnesium or on the magnesium partition.

Thyroxin. Three dogs, numbers 313,314 , and 9, were given $4 \mathrm{mgm}$. of thyroxin subcutaneously, daily, for 27 to 30 days each (Table III). The drug was then discontinued and observations on dogs 313 and 314 were continued at intervals of 1 to 2 weeks, for an additional 32 days. Dog number 313 showed no change either in the total blood magnesium level or in the percentage of bound magnesium. Dog number 314 showed a temporary slight reduction both in the total blood magnesium and in the percentage of bound magnesium. Dog number 9 showed similar changes. The results obtained in these dogs are similar to those observed in normal obese individuals who have received thyroid extract and thyroxin for weight reduction purposes (1). Despite the administration of enough thyroid extract to produce a definite and considerable in- crease in the basal metabolic rate above the normal level, there occurred no increase in the percentage of bound magnesium such as was obtained in patients with true Graves' disease.

Thyrotropic hormone. Four dogs, numbers 2, 8,308 , and 314 , were given 100 to 500 guinea pig units of thyrotropic hormone (Ayerst, McKenna, and Harrison) subcutaneously, daily (Table IV). Dogs numbers 2 and 8 received injections for 16 and 26 days, respectively. The experiments were then discontinued and no further observations were made. Dogs numbers 308 and 314 were injected for 24 and 34 days. The injections were then discontinued and further observations were made for 51 and 43 days.

The results obtained in 3 of the 4 dogs were essentially identical. In 3 dogs, numbers 8,308 , and 314 , following the injection of thyrotropic hormone, there occurred a marked increase in the

TABLE II

Effect of magnesium sulfate on percentage of bound magnesium

\begin{tabular}{|c|c|c|c|c|c|c|c|}
\hline$\underset{\text { num- }}{\text { Dog }}$ & Days & $\begin{array}{c}\text { Total } \\
\mathbf{M g}\end{array}$ & $\underset{\mathbf{M g}}{\text { Bound }}$ & $\underset{\text { num- }}{\text { Dog }}$ & Days & $\begin{array}{c}\text { Total } \\
\mathbf{M g}\end{array}$ & $\underset{\mathbf{M g}}{\text { Bound }}$ \\
\hline 313 & $\begin{array}{c}0 \\
\text { (Con- } \\
\text { trol) }\end{array}$ & $\begin{array}{c}\text { mgm. } \\
\text { per cent } \\
2.59\end{array}$ & $\begin{array}{c}\text { per cent } \\
25.1\end{array}$ & 411 & $\begin{array}{c}0 \\
\text { (Con- } \\
\text { trol) }\end{array}$ & $\begin{array}{c}\underset{\text { per cent }}{\operatorname{mgm} .} \\
2.72\end{array}$ & $\begin{array}{c}\text { per cent } \\
21.7\end{array}$ \\
\hline
\end{tabular}

3 cc. 25 per cent $\mathrm{MgSO}_{4}$ Intravenously Daily

\begin{tabular}{c|r|r|r|r|r|r|r}
\hline & 31 & 2.36 & 20.3 & & 28 & 2.73 & 25.8 \\
& 42 & 2.38 & 22.3 & & 53 & 2.55 & 22.7 \\
75 & 2.57 & 19.3 \\
\hline & & & & & \\
\hline & Injections Discontinued \\
\hline & 109 & 2.50 & 32.4 & & 96 & 2.06 & 17.4 \\
& & & & 142 & 2.94 & 29.2 \\
\hline
\end{tabular}

percentage of bound magnesium above the control level. This increase occurred during the first 3 weeks of injections. Following this initial definite increase, and while the injections were continued, there occurred a drop in the percentage of bound magnesium in one instance to the control level and in two instances, 308 and 314, to the point where there was no circulating bound magnesium (such as we reported to occur in myxedema in the human (1)). In these same 
TABLE III

Effect of thyroxin on total blood magnesium and percentage of bound magnesium

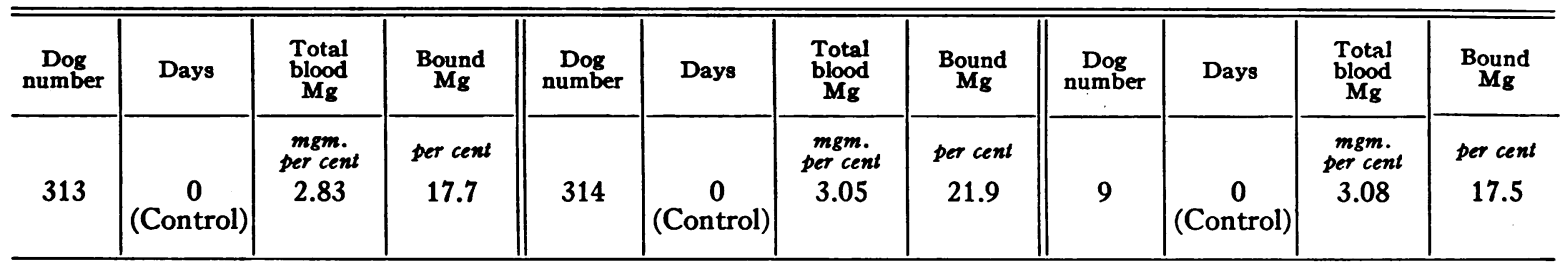

4 mgm. Thyroxin Subcutaneously Daily

\begin{tabular}{|c|c|c|c|c|c|c|c|c|c|}
\hline $\begin{array}{l}18 \\
27\end{array}$ & $\begin{array}{l}2.88 \\
2.61\end{array}$ & $\begin{array}{l}18.1 \\
22.9\end{array}$ & . & $\begin{array}{l}18 \\
27\end{array}$ & $\begin{array}{l}2.89 \\
2.94\end{array}$ & $\begin{array}{l}13.5 \\
18.4\end{array}$ & $\begin{array}{l}20 \\
30\end{array}$ & $\begin{array}{l}2.67 \\
2.50\end{array}$ & $\begin{array}{l}20.2 \\
10.4\end{array}$ \\
\hline
\end{tabular}

Injections Discontinued

\begin{tabular}{l|l|l|l|l|l|l|l|l||}
\hline 36 & 2.86 & 24.1 & & 36 & 2.07 & 17.2 & \\
42 & 2.61 & 27.9 & & 42 & 2.41 & 21.2 & \\
& 59 & 2.69 & 21.2 & & 59 & 2.79 & 22.9 & \\
\hline
\end{tabular}

dogs, blood studies were continued after the injections were stopped, and in both instances, the percentages of bound magnesium returned to a value considerably above the original levels.

Dog number 2 received only 100 guinea pig units of thyrotropic hormone daily for 16 days. During this period of time, there occurred a decrease in the percentage of bound magnesium, not preceded by a previous increase. The experiment inadvertently was not continued beyond the injection period.

\section{COMMENT}

The object of these and experiments subsequently to be reported represents an attempt to identify those factors which may play a part in producing an elevation in the percentage of bound magnesium in Graves' disease. It is interesting that magnesium sulfate, sodium iodide, and thyroxin produce no appreciable change in normal dogs. These results, at least as far as the last two drugs are concerned, are similar to those obtained in normal human

TABLE IV

Effect of thyrotropic hormone on total blood magnesium and percentage of bound magnesium

\begin{tabular}{|c|c|c|c|c|c|c|c|c|c|c|c|c|c|c|c|}
\hline$\underset{\substack{\text { Dog } \\
\text { num- }}}{\text { ber }}$ & Days & $\begin{array}{c}\text { Total } \\
\text { blood } \\
\mathbf{M g}\end{array}$ & $\underset{\mathbf{M g}}{\text { Bound }}$ & $\underset{\substack{\text { Dog } \\
\text { num- } \\
\text { ber }}}{\text { Dom }}$ & Days & $\begin{array}{l}\text { Total } \\
\text { blood } \\
\text { Mg }\end{array}$ & $\underset{\mathbf{M g}}{\text { Bound }}$ & $\begin{array}{c}\text { Dog } \\
\text { num- } \\
\text { ber }\end{array}$ & Days & $\begin{array}{l}\text { Total } \\
\text { blood } \\
\mathbf{M g}\end{array}$ & $\begin{array}{c}\text { Bound } \\
\text { Mg }\end{array}$ & 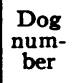 & Days & $\begin{array}{c}\text { Total } \\
\text { blood } \\
\mathbf{M g}\end{array}$ & $\begin{array}{c}\text { Bound } \\
\text { Mg }\end{array}$ \\
\hline 2 & $\left(\begin{array}{c}0 \\
\text { (Control) }\end{array}\right.$ & $\begin{array}{c}\underset{\text { per cent }}{\operatorname{mgm} .} \\
2.51\end{array}$ & $\begin{array}{c}\text { per cent } \\
20.0\end{array}$ & 8 & $\begin{array}{c}0 \\
\text { (Control) }\end{array}$ & $\begin{array}{c}\text { mgm. } \\
\text { per cent } \\
2.56\end{array}$ & \begin{tabular}{|c|} 
per cent \\
8.2
\end{tabular} & 308 & $\begin{array}{c}0 \\
(\text { Control })\end{array}$ & $\mid \begin{array}{c}\text { per cent } \\
2.99\end{array}$ & $\begin{array}{c}\text { per cent } \\
12.0\end{array}$ & 314 & $\mid \begin{array}{c}0 \\
\text { (Control) }\end{array}$ & $\begin{array}{c}\underset{\text { per cent }}{\operatorname{mgm}} \\
2.80\end{array}$ & $\begin{array}{c}\text { per cent } \\
13.1\end{array}$ \\
\hline \multicolumn{4}{|c|}{$\begin{array}{c}100 \text { G. P. Units Thyrotropic } \\
\text { Hormone Subcutaneously } \\
\text { Daily }\end{array}$} & \multicolumn{12}{|c|}{500 G. P. U. Thyrotropic Hormone Subcutaneously Daily } \\
\hline & $\begin{array}{l}13 \\
16\end{array}$ & $\begin{array}{l}2.78 \\
2.62\end{array}$ & $\begin{array}{l}15.8 \\
11.8\end{array}$ & & $\begin{array}{l}13 \\
19 \\
26\end{array}$ & $\begin{array}{l}3.06 \\
2.96 \\
2.53\end{array}$ & $\begin{array}{r}25.5 \\
12.4 \\
8.3\end{array}$ & & $\begin{array}{l}10 \\
20 \\
24\end{array}$ & $\begin{array}{l}2.25 \\
3.05 \\
2.88\end{array}$ & $\begin{array}{l}19.5 \\
26.9 \\
22.2\end{array}$ & & $\begin{array}{l}10 \\
17 \\
24 \\
34\end{array}$ & $\begin{array}{l}3.00 \\
2.12 \\
2.96 \\
2.48\end{array}$ & $\begin{array}{r}25.0 \\
17.4 \\
0.0 \\
5.2\end{array}$ \\
\hline
\end{tabular}

Injections Discontinued

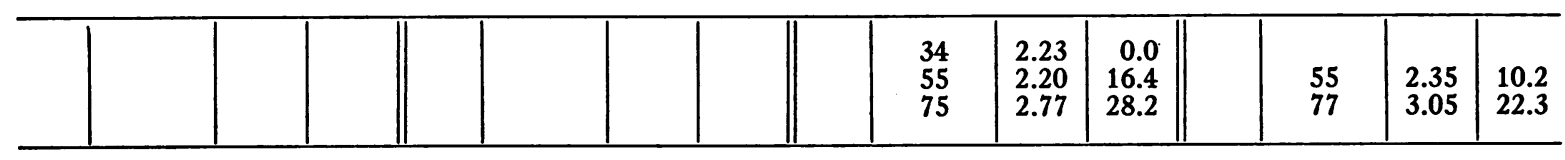


beings. It is worth while emphasizing that the experimental results, here reported with thyroxin, are in harmony with the clinical impression that hyperthyroidism due to thyroid administration is not identical with Graves' disease.

The experimental results obtained in the dogs receiving the thyrotropic hormone are very different from those obtained with the other drugs. Following the administration of this hormone, there occurs a very considerable increase in the percentage of bound magnesium, such as we have obtained clinically only in patients with Graves' disease. This initial increase in the percentage of bound magnesium in the experimental animals is followed by a marked drop to levels seen only in myxedema in the human. This spontaneous decline in the percentage of bound magnesium, occurring during or directly after the course of the injections, would suggest that the administration of thyrotropic hormone eventually results in the development of some compensatory mechanism which vitiates the effect of the thyrotropic hormone as far as the magnesium partition is concerned. It is, perhaps, not unlikely that this may be due to the production of an anti-thyrotropic factor or hormone. This thesis is in part corroborated by results obtained in one preliminary experiment in which thyrotropic hormone was administered to a totally hypophysectomized dog. In this animal, the administration of thyrotropic hormone resulted in a persistent and sustained increase in the percentage of the bound magnesium with no tendency to fall to control or below control levels during the administration of the hormone.

\section{SUMMARY}

1. Experiments are reported on the effects of the administration of magnesium sulfate, sodium iodide, thyroxin, and thyrotropic hormone on the blood magnesium partition in normal dogs.

2. The administration of magnesium sulfate, sodium iodide, and thyroxin produced no appreciable change in the percentage of bound magnesium.

3. Injections of thyrotropic hormone produced an increase in the percentage of bound magnesium, followed by a reduction to levels considerably below the control values. After the injections of the drug were discontinued, the percentage of bound magnesium increased beyond the control levels.

4. The possible significance of these findings in relation to clinical Graves' disease is discussed.

\section{BIBLIOGRAPHY}

1. Soffer, L. J., et al., Ultrafiltrable magnesium in hyperthyroidism. J. Clin. Invest., 1939, 18, 597.

2. Soffer, L. J., et al., Magnesium partition studies in Graves' disease and in clinical and experimental hypothyroidism. J. Clin. Invest., 1941, 20, 429.

3. Dine, R. F., and Lavietes, P. H., Serum magnesium in thyroid disease. J. Clin. Invest., 1942, 21, 781.

4. Cope, C. L., and Wolff, B., Ultrafilterable serum magnesium in hyperthyroidism. Biochem. J., 1942, 36, 413.

5. Briggs, A. P., Colorimetric method for determination of small amounts of magnesium. J. Biol. Chem., 1922, 52, 349.

6. Kuttner, T., and Lichtenstein, L., Micro colorimetric studies. II. Estimation of phosphorus: Molybdic acid-stannous chloride reagent. J. Biol. Chem., 1930, 86, 671. 